\title{
Variceal Bleeding in Patients with Initation of Sofosbuvir and Ribavirin - Case Reports
}

\author{
Sadiq Memon ${ }^{1}$, Madiha Zaki ${ }^{* 2}$, Shahzad Ali Jiskani ${ }^{3}$ \\ ${ }^{1}$ Department of Gastroenterology, Asian Institute of Medical Sciences, Hyderabad, Pakistan. \\ ${ }^{2}$ Department of Gastroenterology, Indus Medical College Hospital, Tando Muhammad Khan, Pakistan. \\ ${ }^{3}$ Department of Pathology, Indus Medical College Hospital, Tando Muhammad Khan, Pakistan.
}

\begin{abstract}
Sofosbuvir is an oral nucleoside analogue and potent inhibitor of the Hepatitis C virus (HCV) RNA polymerase that is used in combination with other antiviral agents to treat chronic Hepatitis $\mathrm{C}$ Nevertheless, and for unknown reasons, successful antiviral therapy of Hepatitis $\mathrm{C}$ with Sofosbuvir and other direct acting agents in patients with cirrhosis is occasionally complicated by hepatic decompensation. Here we describe 2 case report of upper gi bleed at initial days of treatment with Sofosbuvir and Ribavirin.
\end{abstract}

Keywords: Variceal bleeding, Sofosdbuvir, Ribavirin, Heptitis C, Nucleoside analogue, Antiviral.

\section{INTRODUCTION}

$\mathrm{HCV}$ is the one of most common infectious disease in worldwide including Asia with increases prevalence of end stage liver disease [1]. According to WHO around 500,000 thousands death attributed each year due to $\mathrm{HCV}$ infection [2]. Before 2014 the Interferon and Ribavirin are cornerstones of HCV treatment, but these drugs have poor safety profile and limited efficacy in special group of cohorts Q hepatic decompensation [3]. Now since 1 to 2 years Sofosbuvir and Ribavirin option revolutionized the treatment options for patients with advanced liver disease cause by Hepatitis C [4]. However their effects on viral suppression, clinical outcome and safety profile in patients with advanced liver disease is still not yet been successfully proved.

Here we describe 2 case reports of Upper GI Bleeding within 7-10 days of started of Sofosbuvir and Ribavirin. The purpose of these 2 cases is to raise question of safety issues of DAA (direct acting agents) in advance liver disease.

\section{CASE 1}

A 64 year old male with genotype 3a HCV Decompensated cirrhosis, Child Pugh 10 and Meld score of 16 also had history of ascites which were well controlled on spironolactone 100 $\mathrm{mg}$ daily, Pre-treatment HCV RNA were $6.0 \times 104 \mathrm{IU} / \mathrm{ml}$ were started treatment with Sofosbuvir and Ribavirin on 7 th day of treatment he were admitted in our emergency department with 3 episodes of hematemesis and melena. On admission he appeared pale, vital sign were notable for tachycardia and mild tachypenia his physical examination revealed anemia and moderate splenomegaly and ascites. Complete Blood Count was significant for pancytopenia $(\mathrm{Hb} 8.7 \mathrm{~g} / \mathrm{dl}$,

*Address correspondence to this author at the Department of Gastroenterology, Indus Medical College Hospital, Tando Muhammad Khan, Pakistan. Email: madiyaah@gmail.com
TLC $2.800 /$ cumm and platelets $120,00 \times 109 / \mathrm{ml}$ ), after resuscitation with fluids and medical treatment protocols of ugib patient underwent for EGD and found to be have Grade 4 Esophageal varices with sputter at $35 \mathrm{~cm}$ of esophagus which was targeted and ligated rest of esophageal varices were also banded, (Fig. 1) following band ligation patient demonstrated excellent improvement and well tolerated Sofosbuvir and Ribavirin and remained clinically stable .

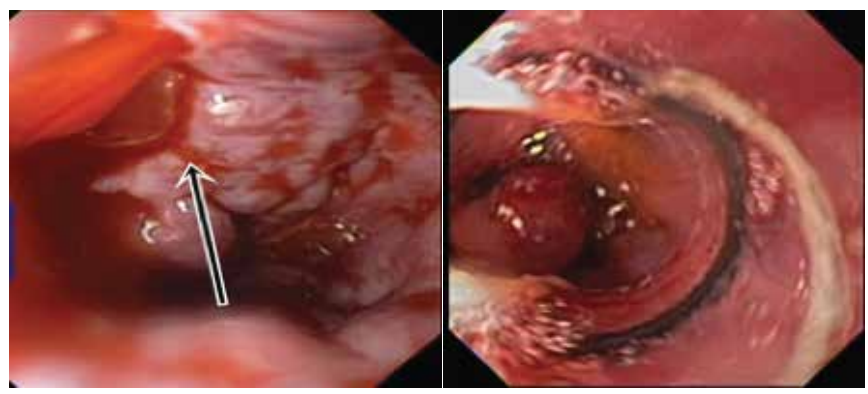

Fig. (1). Spurtter at $35 \mathrm{~cm}$ of Esophagus, successfully Ligation of Spurtter.

\section{CASE 2}

A 55 years old male with history of chronic Hepatitis $\mathrm{C}$-induced decompensation presented to the emergency department for hematemesis. The patient was alert, trachycardiac $(140 \mathrm{bpm})$ and hypotensive $(87 / 36 \mathrm{mmHg})$. On physical examination found to be have splenomegaly. Blood tests showed $\mathrm{Hb} 6.8 \mathrm{~g} / \mathrm{dl}$, TLC 14,000/cumm and platelets $92,000 \times 109$. His viral load was $894856 \mathrm{IU} / \mathrm{ml}$ and model of end stage liver disease were 15 . After adequate resuscitation patient underwent urgent upper GI endoscopy which shows active bleeding from fundal varix that was successfully controlled with $2 \mathrm{ml}$ of histoacryl injection (Fig. 2). 


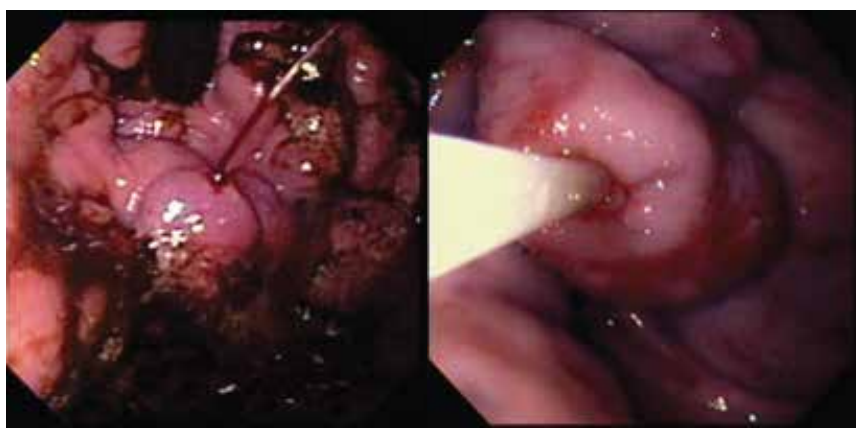

Fig. (2). Active Bleeding from Fundal Varix, Histoacryl Injection.

\section{DISCUSSION}

Current case reports describe the first experience of Upper GI Bleeding in association with newly start of Sofosbuvir and Ribavirin .The mechanism of underlying UGIB is currently unknown however the following factors may results this adverse effect ; 1) worsening of portal hypertension due to activations of inflammation process at initial stage of $\mathrm{HCV}$ treatment with Sofosbuvir and Ribavirin [5]. 2) Rare, but striking liver injury associated with Sofosbuvir is hepatic decompensation occurring in patients with pre-existing cirrhosis. The cause of this decompensation is not clear, but it may represent a response to $\mathrm{HCV}$ viral eradication (on-target effect) rather than toxicity of the administered antiviral agents (off-target effect on the liver). Alternatively, the injury may be coincidental and unrelated to therapy [6]. 3) Sofosbuvir metabolized in the liver largely via the cytochrome P450 system, predominantly CYP $1 \mathrm{~A} 2$. That may reflect changes in the immune status resulting from the suppression of $\mathrm{HCV}$ replication and injury [7].

\section{CONCLUSION}

According to the results of available studies to date, the use of DAA in patients with advance liver disease is reasonable until more data are available, antiviral treatment in patients with advance liver disease should exclusively Monitored in specialized centers. According to results of our study before starting of DAA in advance liver patients varices should be screen and ligated along with that beta blocker should be initiated with close monitoring of sign of further hepatic decompensation.

\section{AUTHORS' CONTRIBUTION}

All authors have equally contributed.

\section{CONFLICT OF INTEREST}

Declared none.

\section{ACKNOWLEDGEMENTS}

Declared none.

\section{REFERENCES}

[1] Cooke GS, Lemoine M, Thursz M, et al. Viral hepatitis and the global burden of disease: A need to regroup. J Viral Hepatol 2013; 20: 600-1. DOI: 10.1111/jvh.12123

[2] Mohd-Hanafiah K, Groeger J, Flaxman AD, Wiersma ST. Global epidemiology of Hepatitis $\mathrm{C}$ virus infection: new estimates of age-specific antibody to $\mathrm{HCV}$ seroprevalence. Hepatology 2013; 57: 1333-42. DOI: 10.1002/hep.26141

[3] Feeney ER, Chung RT. Antiviral treatment of Hepatitis C. BMJ 2014; 348: g3308. DOI: 10.1136/bmj.g3308

[4] Zeuzem S, Dusheiko G, Salupere R, et al. Sofosbuvir + Ribavirin for 12 or 24 weeks for patients with $\mathrm{HCV}$ genotype 2 or 3: The VALENCE trial. Hepatology 2013; 58(Suppl): 733.

[5] Aller MA, Arias J. Portal systemic collateral development: Is it a trophic adaption mechanism to hepatic deprivation? J Gastroenterol Hepatol 2006; 21: 1643-5. DOI: 10.1111/j.1440-1746.2006.04508.x

[6] Höner Zu Siederdissen C, Maasoumy B, Deterding K, et al. Eligibility and safety of the first interferon-free therapy against Hepatitis C in a real-world setting. Liver Int 2015; 35: 1845-52. DOI: 10.1111/liv.12774

[7] Readler LA. Once-a-day horvonit (Ledipasvir plus Sofosbuvir), a new oral combination for the treatment of patients with genotype 1 chronic hepatitis c infection. Am Health Drug Benefits 2015; 8(Suppl Issue): 54-8. 